\title{
The clinical outcome and microbiological profile of bone-anchored hearing systems (BAHS) with different abutment topographies: a prospective pilot study
}

\author{
Margarita Trobos $^{1} \mathbb{D} \cdot$ Martin Lars Johansson ${ }^{1,2} \mathbb{D} \cdot$ Sofia Jonhede $^{2} \cdot$ Hanna Peters $^{2} \cdot$ Maria Hoffman $^{1} \cdot$ \\ Omar Omar ${ }^{1}$ (D) Peter Thomsen ${ }^{1}$ (D) Malou Hultcrantz ${ }^{3}$ (D)
}

Received: 29 November 2017 / Accepted: 20 March 2018 / Published online: 5 April 2018

(c) The Author(s) 2018

\begin{abstract}
Purpose In this prospective clinical pilot study, abutments with different topologies (machined versus polished) were compared with respect to the clinical outcome and the microbiological profile. Furthermore, three different sampling methods (retrieval of abutment, collection of peri-abutment exudate using paper-points, and a small peri-abutment soft-tissue biopsy) were evaluated for the identification and quantification of colonising bacteria.

Methods Twelve patients, seven with machined abutment and five with polished abutment, were included in the analysis. Three different sampling procedures were employed for the identification and quantification of colonising bacteria from baseline up to 12 months, using quantitative culturing. Clinical outcome measures (Holgers score, hygiene, pain, numbness and implant stability) were investigated.

Results The clinical parameters, and total viable bacteria per abutment or in tissue biopsies did not differ significantly between the polished and machined abutments. The total CFU/mm² abutment and CFU/peri-abutment fluid space of anaerobes, aerobes and staphylococci were significantly higher for the polished abutment. Anaerobic bacteria were detected in the tissue biopsies before BAHS implantation. Anaerobes and Staphylococcus spp. were detected in all three compartments after BAHS installation. For most patients (10/12), the same staphylococcal species were found in at least two of the three compartments at the same time-point. The common skin coloniser Staphylococcus epidermidis was identified in all patients but one (11/12), whereas the pathogen Staphylococcus aureus was isolated in five of the patients. Several associations between clinical and microbiological parameters were found.

Conclusions There was no difference in the clinical outcome with the use of polished versus machined abutment at 3 and 12 months after implantation. The present pilot trial largely confirmed a suitable study design, sampling and analytical methodology to determine the effects of modified BAHS abutment properties.
\end{abstract}

Level of evidence 2. Controlled prospective comparative study.

Keywords Abutment $\cdot$ Bacteria $\cdot$ BAHS $\cdot$ Bone-anchored hearing system $\cdot$ Skin $\cdot$ Staphylococcus

Margarita Trobos and Martin Lars Johansson contributed equally to this work.

Electronic supplementary material The online version of this article (https://doi.org/10.1007/s00405-018-4946-z) contains supplementary material, which is available to authorized users.

Margarita Trobos

margarita.trobos@biomaterials.gu.se

1 Department of Biomaterials, Institute of Clinical Sciences, Sahlgrenska Academy, University of Gothenburg, P.O.

Box 412, 40530 Gothenburg, Sweden

\section{Introduction}

The percutaneous bone-anchored hearing system (BAHS) has been used clinically for over 30 years and is the most commonly used system for patients with conductive or

Oticon Medical AB, Askim, Sweden

3 Department of Otorhinolaryngology, Karolinska University Hospital, Stockholm, Sweden 
mixed hearing losses. The long-term success rate is high, with a low rate of major complications. Nevertheless, adverse skin reactions continue to be common complications $[1,2]$. Most reactions are mild to moderate, but still cause inconvenience for patients and additional costs for the health care system, supporting the strong need to optimise the conditions of the abutment-skin interface.

After surgical installation of implants, inflammation followed by tissue repair are the two major biological events elicited in the bone and soft tissue in immediate contact with the components of the BAHS. The detailed mechanisms of these responses such as how they are affected by the host, local tissue conditions, surgical protocols and material properties, have largely been derived from experimental studies and other applications (e.g. oral implants) [3-5]. A key process, ultimately resulting in a stable fixation of the BAHS, is the osseointegration of the fixture in the temporal bone. In contrast, the nature of a long-term and optimal soft tissue adaptation to the abutment material, penetrating the skin, is incompletely understood. During adverse tissue responses to BAHS, the surrounding immune cells and microorganisms may be localised in several different compartments: on the surface of the abutment, in the exudate around the abutment, and in the surrounding connective tissue [6-9]. A major reason why the structural and functional adaptation of the implanted material to the bone and soft tissue is not trivial, is the concept "race for the surface" between host cells and microorganisms [10]. Furthermore, the presence of a foreign material reduces the minimum dose needed to cause infection by 10,000-fold [11]. An aggravating factor for percutaneous implants is the breach of the skin barrier, making the entire system vulnerable for colonisation of microorganisms.

The physicochemical and topographical properties of biomaterials are key variables for achieving a desired host tissue response [12]. Recently, hydroxyapatite (HA)-coated titanium abutments were introduced clinically for BAHS [13]. The intention was to achieve integration between the abutment material and the dermal tissue, thereby reducing the pocket formation and bacterial colonisation on the abutment surface. Although dermal adherence has been demonstrated experimentally, the short- and long-term clinical benefits have varied $[4,13,14]$. Moreover, shear and strain forces in the soft tissue may induce adverse inflammatory responses [15]. Here, we hypothesise that an ultra-smooth abutment, achieved by electropolishing, will prevent adhesion and integration allowing the soft tissue to move freely around the abutment, counteracting the mechanical discrepancy. Electropolishing is a process for material removal acting selectively on micro-rough areas resulting in a microscopically smooth and shiny surface while maintaining the macroscopic structure intact [16].
Studies evaluating the role of the microbial component for the tissue response and outcome for BAHS are limited. Using electron microscopy, fungi and bacteria have been observed on abutments obtained from humans, both free on the surface, in the form of biofilm and internalised in macrophages and granulocytes [6-8]. In a clinical study, the presence of Staphylococcus aureus in the soft tissue adjacent to the abutment was associated with a clinical manifestation of skin irritation [17]. Sebaceous glands connected to hair follicles secrete sebum, acting as an antibacterial shield that protects and lubricates the skin and hair. The relatively anoxic conditions of sebaceous glands can however promote the growth of facultative anaerobes like Propionibacterium acnes [18]. Furthermore, the skin microbiota is dependent on the body site, with the lowest bacterial diversity found in sebaceous sites like the retro-auricular crease (behind the ear) with 15 phylotypes [19, 20]. Propionibacterium spp., Staphylococcus spp. and Corynebacterium spp. predominate in sebaceous sites of the skin in culture-based [21] and genomic [20] studies. However, details on how the microflora of the retro-auricular crease/scalp changes in response to percutaneous abutments connected to osseointegrated implants are unknown.

The aims of this prospective clinical pilot study were to: (1) evaluate and compare abutments with different topologies (machined versus polished) with respect to the clinical outcome and the microbiological profile up to 1 year, and (2) evaluate three different sampling methods (retrieval of abutment, collection of peri-abutment exudate using paperpoints, and small peri-abutment soft-tissue biopsy) for the identification and quantification of colonising bacteria.

\section{Materials and methods}

\section{Ethics}

The study was performed in consistency with the Declaration of Helsinki (Washington 2002), ISO 14155:2011, approved by the Regional Ethical Review Board of Stockholm, Sweden (2014/1566-31/2) and registered at clinicaltrials.gov (NCT02304692).

\section{Patients and implants}

Adult patients, eligible for BAHS, were enrolled and the surgery was performed in a tertiary university hospital in Sweden between November 2014 and December 2015. Informed consent was obtained from all participants. Exclusion criteria were (1) inability or unwillingness to participate in follow-up; (2) skin thickness of $>10 \mathrm{~mm}$ since soft tissue reduction would then be required; (3) diseases known to compromise bone quality or (4) previous 
irradiation in the implant area. Enrolled patients were allocated consecutively to the control (machined abutment) and the test (polished abutment) groups. Patients received the Ponto Wide implant (diameter $4.5 \mathrm{~mm}$, length $4 \mathrm{~mm}$ ), pre-mounted with either a machined or an electro-polished abutment of suitable length (diameter $5 \mathrm{~mm}$, length 6,9 or $12 \mathrm{~mm}$ ) (Oticon Medical, Askim Sweden). The implants were installed using the minimally invasive Ponto surgery (MIPS) technique. Here, the drilling and installation is performed through a biopsy incision, eliminating the need for a linear incision and exposure of the bone bed [22, 23]. In brief, the main steps of the MIPS technique are: (1) the site for implant is estimated at $50-55 \mathrm{~mm}$ from the ear canal and skin thickness is determined prior to application of local or general anaesthetics; (2) a 5-mm punch biopsy is used for making a circular incision; (3) the cannula is inserted in the circular incision; (4) step-wise drilling is performed through the cannula; (5) the cannula is removed and the implant installed and, finally, (6) a soft healing cap is attached to the abutment and a suitable dressing is applied. After the surgery, the patients were assessed at 5-10 days, 3-12 weeks, 12 weeks, 6 and 12 months following the regular practice of the clinic. In case of adverse soft-tissue reaction, local treatment with Fucidin ${ }^{\circledR}$ ointment containing the antibiotic fusidic acid and corticosteroids (Leo Pharma, Malmo, Sweden) was applied. All data were recorded in paper-based Case Report Forms.
A summary of the examinations and parameters is found in Fig. 1.

\section{Study design}

This study was a single-centre, prospective, controlled, case series, clinical investigation. The primary objective was to compare the clinical outcomes and bacterial colonisation between machined and polished abutments 3 months after surgery.

\section{Abutment design}

Abutments (commercially pure titanium grade 4) were either left untreated with a machined surface (control) or electropolished (test) using an ElpoLux TI electrolyte (ElpoChem AG, Volketswil, Switzerland). The inner cavities of the abutment were left untreated by means of masking. Abutments were ultrasonically cleaned stepwise in liquid detergent, deionised water, ethanol and dried in filtered air. All abutments and implants were sterilised by beta-irradiation in a plastic blister.

\section{Surface characterisation}

The chemical composition of the abutment surfaces was analysed using Auger electron spectroscopy (AES) (PHI 700 Scanning Auger Microprobe, $3.0 \mathrm{keV}$, Physical Electronics
Fig. 1 Study outline and schematics of sampling of tissue with biopsy, peri-abutment fluid with paper-points and retrieval of abutment, at baseline, 3 and 12 months. Parallel to the microbiological sampling, clinical measurements were collected and the stability of the implant assessed with resonance frequency analysis (RFA)

\begin{tabular}{lllll}
$\mathbf{0}$ day & $\mathbf{1}$ week & $\mathbf{3}$ months & $\mathbf{6}$ months & $\mathbf{1 2}$ months \\
\hline Surgery & Clinical & Clinical & Clinical & Clinical \\
RFA & RFA & RFA & RFA & RFA \\
Tissue biopsy & Paper-points & & Paper-points \\
& & Tissue biopsy & & Tissue biopsy \\
& Abutment & & Abutment
\end{tabular}
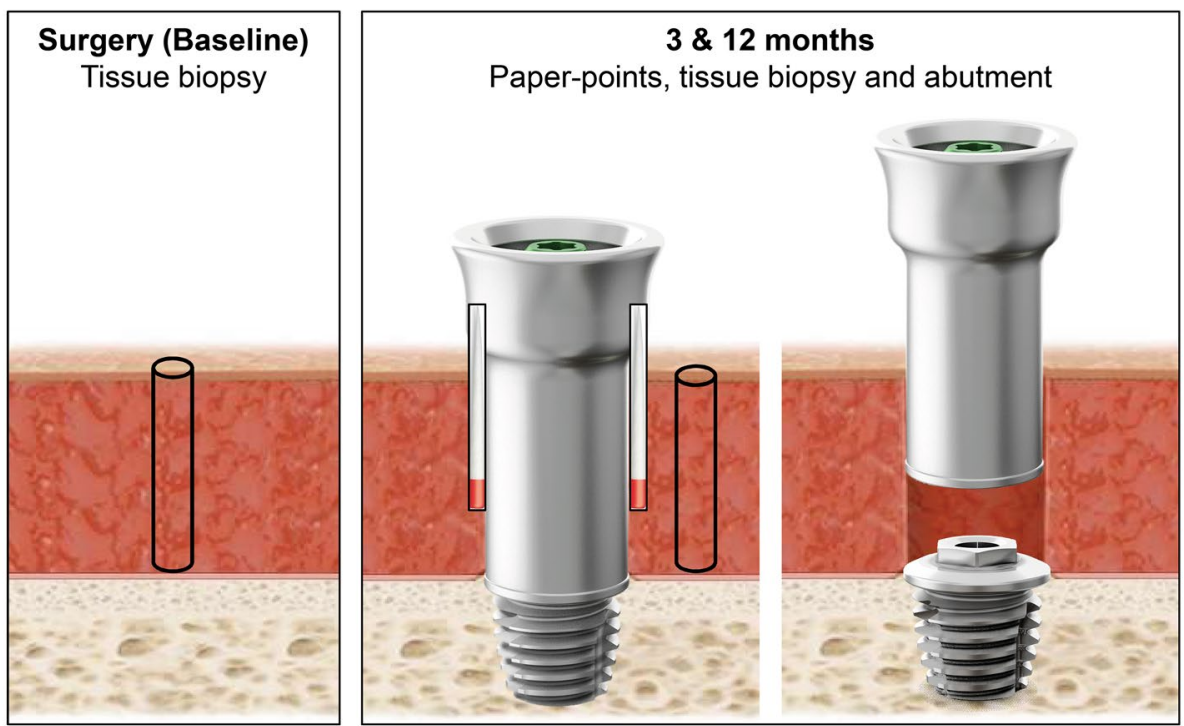
Inc., Chanhassen, MN, USA). Scanning electron microscopy (SEM; Leo Ultra 55 FEG-SEM, Zeiss, Oberkochen, Germany) operating at $10 \mathrm{kV}$ was used for qualitative assessment of the surface roughness. Surface topography was obtained using non-contact white light interferometry (WYKO NT9100, Veeco Instruments Inc., Plainview, NY, USA). Surface wettability was determined by contact angle $\left(\mathrm{CA}^{\circ}\right)$ measurement at room temperature. A $3-\mu \mathrm{L}$ drop of deionised water was dispensed on the cylindrical part of the abutment using a syringe and the static $\mathrm{CA}^{\circ}$ was determined using an optical tensiometer (Theta Lite, Biolin Scientific, Gothenburg, Sweden), and calculated with One Attension software (version 2.6, Biolin Scientific).

\section{Study interventions}

At the surgery visit, the implant site was disinfected with ethanol $(70 \% \mathrm{w} / \mathrm{v})$. After local anaesthesia, a skin biopsy was collected at the predetermined retro-auricular position of the abutment using a $1 \mathrm{~mm}$ biopsy punch (Fig. 1). The biopsy was preserved in an $\mathrm{ESwab}^{\mathrm{TM}}$ collection and transport tube containing $1 \mathrm{~mL}$ Liquid Amies medium (Copan Italia S.p.A., Brescia, Italy) for baseline bacterial cultures. At the 3 and 12 months follow-up visits, sampling of periabutment exudate for bacterial cultures was performed using two paper-points (Roeko ISO, size 45, Coltene, Langenau, Germany) inserted in the space between the abutment and surrounding skin (anterior and posterior locations). They were left for $60 \mathrm{~s}$, pooled and preserved in $1 \mathrm{~mL}$ ESwab ${ }^{\mathrm{TM}}$ medium for microbiological cultures. Thereafter the abutment was released from the implant. A sterile bottom- and top lid was mounted on the abutment to seal the interior to ensure that the bacterial count reflected only the outer surface of the abutment. The assembly was thereafter placed in $2 \mathrm{~mL}$ ESwab ${ }^{\mathrm{TM}}$ medium (2 pooled tubes) for subsequent cultures of bacteria. The skin was disinfected and local anaesthesia was administered to the area before installing a new abutment of the same type (test or control). A soft tissue biopsy was collected at the border of the abutment using a 1-mm biopsy punch and preserved in $1 \mathrm{~mL} \mathrm{ESwab}{ }^{\mathrm{TM}}$ medium for subsequent microbiological cultures. Samples were kept submerged at $4{ }^{\circ} \mathrm{C}$ before transportation and after arrival to the Microbiology Laboratory (Department of Biomaterials, University of Gothenburg, Sweden) for processing and analysis. Samples were transported at room temperature during 5-24 h.

\section{Bacteriological evaluation}

The soft tissue biopsies, paper-points and retrieved abutments were processed within 2 days after retrieval. Total aerobic and anaerobic bacteria were measured on abutment (CFU/abutment), paper-points (CFU/paper-points) and in soft tissue samples (CFU/biopsy). Additionally, staphylococci, enterococci, Escherichia coli, and Pseudomonas aeruginosa were quantitated using selective media. The protocol was adapted from UK Standards for Microbiology Investigations [24] and Charalampakis [25] with slight modifications.

\section{Homogenisation of samples and dislodging of bacteria}

Soft tissue biopsies were homogenised in the ESwab ${ }^{\mathrm{TM}}$ medium using a tissue homogeniser (T10 basic, IKA, Staufen, Germany) for 5 min with progressively increased speed. The ESwab ${ }^{\mathrm{TM}}$ tube containing two paper-points was vortexed at maximum speed (3200 rpm) for $1 \mathrm{~min}$ to dislodge bacteria. To remove the bacteria adherent on the abutments, the $\mathrm{ESwab}^{\mathrm{TM}}$ tubes containing the abutments were vortexed for $30 \mathrm{~s}$ ( $3200 \mathrm{rpm}$ ), followed by $5 \mathrm{~min}$ of sonication at $40 \mathrm{kHz}$ and additional vortexing for $30 \mathrm{~s}$.

\section{Viability counting (CFU)}

A total of sixtenth-dilution series were made in $0.9 \%$ saline from each homogenised sample. A volume of $100 \mu \mathrm{l}$ from dilution $6(1: 1,000,000)$, dilution $4(1: 10,000)$, dilution 2 (1:100) and undiluted sample (1:1) was spread on duplicate agar plates of the following media (Media Department, Clinical Microbiology laboratory, Sahlgrenska University Hospital, Sweden): 5\% horse blood Columbia agar (H207) for aerobic bacteria, brucella agar (B350) for anaerobic bacteria, staphylococci agar (S316), enterococci agar (E370), and CHROMagar ${ }^{\mathrm{TM}}$ Orientation (K181) (CHROMagar, Paris, France). All plates, except brucella, were incubated aerobically at $37{ }^{\circ} \mathrm{C}$ and $5 \% \mathrm{CO}_{2}$ for 2 days until colonies were counted. Brucella plates were incubated under anaerobic conditions (AnaeroJar ${ }^{\mathrm{TM}}$ and AnaeroGen ${ }^{\mathrm{TM}}$ anaerobic atmosphere generation system; Oxoid Ltd, Hampshire, UK) at $37^{\circ} \mathrm{C}$ for 5 days before $\mathrm{CFU}$ counting.

A total of $100 \mu \mathrm{L}$ were transferred from the undiluted homogenised specimen into one TAS (thioglycolate) broth tube (Media Department, Sahlgrenska University Hospital) and incubated under aerobic conditions for 5 days for enrichment and to increase detection. The TAS tube was read (positive/negative growth), and re-plated in case of negative agar cultures.

At least one colony from each positive plate was subcultured and stored at $-80{ }^{\circ} \mathrm{C}$.

\section{Staphylococcal species identification}

One colony was re-suspended in $5 \mathrm{~mL} 0.9 \%$ saline and $100 \mu \mathrm{L}$ was dispensed in each well of an API ${ }^{\circledR}$ Staph strip (bioMérieux SA, Marcy l'Etoile, France), containing 20 miniature biochemical tests and lysostaphin resistance 
test, and incubated overnight at $37{ }^{\circ} \mathrm{C}$. After addition of the reagents, the strips were read for their specific colour pattern, generating an identification numerical profile. The APIweb $^{\text {TM }}$ software (bioMérieux SA) was used to obtain the organism identification that corresponded to the biochemical or numerical profile of the strip.

\section{Statistics}

Independent t-test was used for the comparison between test and control groups with respect to chemical and topographical surface parameters, mean CFU/abutment, CFU/ tissue biopsy, and CFU/paper-points at 3 months, for the comparisons of mean CFU/abutment and CFU/paper-points between time-points ( 3 and 12 months) as well as for the distribution of Holgers score over observations.

To compare the clinical outcomes between the groups, Mann-Whitney $U$ test was performed for continuous variables and Fisher's exact test for ordered categorical and dichotomous variables. One-way ANOVA followed by Tukey's post hoc test was employed for the comparison of CFU/tissue biopsy between the three time-points (baseline, 3 , and 12 months), and for the comparison between the three sampling methods at each time-point. Pearson correlation was used to evaluate the relationship between clinical and microbiological data, both using test and control groups as separate and pooled. All variables entered in the correlation analysis are described in Online Resource 1.

All statistical analyses were executed using SPSS software (Versions 23.0.0.0, IBM Corporation, USA), and a level of significance of $p<0.05$ was adopted for all tests.

\section{Results}

\section{Surface characterisation}

AES showed a predominance of $\mathrm{Ti}, \mathrm{O}$ and $\mathrm{C}$ on both abutment surfaces, with minor contamination of $\mathrm{Ca}, \mathrm{Cl}$ and $\mathrm{P}$. The interferometry analysis of surface roughness on the microscale demonstrated a smoother surface for the polished abutment compared to the machined. Although, both abutment types were hydrophilic, the water contact angle was significantly lower for the polished abutment compared to the machined (mean difference of $18.5 \mathrm{CA}^{\circ}$ ). The complete surface characterisation data are summarised in Online Resource 2.

\section{Clinical outcome}

Baseline characteristics and surgery data were similar between the two study groups (Table 1). Twelve of the included patients who received either a machined (control, $n=7$ ) or an electropolished (test, $n=5$ ) abutment, and completed the 3 months sampling were included in this analysis.

Two implants in the control group were lost during the follow-up period between 3 and 12 months. Clinically relevant adverse skin reactions (Holgers score $\geq 2$ ) were observed for two patients in the test group versus none in the control (Table 1). For one patient, the adverse soft-tissue reactions resulted in removal of the polished abutment. The clinical outcome measures (Holgers score, hygiene, pain, numbness and implant stability; ISQ) did not differ significantly between test and control after 3 and 12 months. The comparisons between 3 and 12 months for each clinical outcome measure were performed on pooled data and did not demonstrate any significant difference (Table 1). Local antibiotic treatment was administered to patients experiencing an adverse soft tissue reaction (three out of seven (43\%) in the machined group versus two out of five (40\%) in the polished group).

\section{Bacteriological outcome}

The total viable counts of the evaluated groups of bacteria per abutment (Fig. 2a) or in tissue biopsies (Fig. 2c), were not significantly different between the test and control groups at 3 months. Considering the effect of the additional surface area contributed by the microstructure $\left(S_{\mathrm{dr}}\right.$ in Online Resource 2) the total CFU/ $\mathrm{mm}^{2}$ of anaerobes, aerobes and staphylococci, was significantly higher on the polished abutment surface compared to the rougher machined surface (Fig. 2b).

In the peri-abutment fluid space (paper-points), significantly higher count of anaerobes, aerobes and staphylococci were demonstrated for the test group compared with the control group (Fig. 2d). Escherichia coli was found in the fluid space at 3 months (Fig. 2d) and in all three compartments at 12 months (Fig. 2e). At 3 months, enterococci were only retrieved from one machined abutment (Fig. 2a, b) and from paper-points taken from one polished abutment (Fig. 2d). At 12 months enterococci were only isolated from paper-points (Fig. 2e). Pseudomonas aeruginosa was not found in any of the compartments at any time-point.

At baseline, the soft tissue was mainly colonised with anaerobic bacteria (Fig. 2e). Anaerobic bacteria were detected in all compartments after 3 and 12 months. The total number of isolated anaerobes was significantly greater on abutments than in tissues at 3 and 12 months.

At baseline, aerobic bacteria were detected in the soft tissue only in one patient (who had the abutment subsequently removed due to adverse skin reactions). At both 3 and 12 months, the total aerobic and staphylococcal viable counts were significantly higher on the abutments compared to the tissue biopsies and paper-points. The number of aerobic bacteria in the tissue biopsies increased significantly 
Table 1 Baseline demographics, surgery characteristics and clinical outcome

\begin{tabular}{|c|c|c|c|c|}
\hline Baseline demographics & Machined $(n=7)$ & Polished $(n=5)$ & & \\
\hline Age (years); $n(\mathrm{SD})$ & $64.4(25.1)$ & $46.2(24.1)$ & & \\
\hline Gender; $n(\%)$ & & & & \\
\hline Male & $4(57.1)$ & $2(40.0)$ & & \\
\hline Female & $2(28.6)$ & $3(60.0)$ & & \\
\hline Type of hearing loss; $n(\%)$ & & & & \\
\hline $\begin{array}{l}\text { Acquired conductive/mixed hearing } \\
\text { loss }\end{array}$ & $3(42.9)$ & $3(60.0)$ & & \\
\hline Single-sided deafness & $2(28.6)$ & $1(20.0)$ & & \\
\hline Congenital conductive hearing loss & $2(28.6)$ & $1(20.0)$ & & \\
\hline Smoking; $n(\%)$ & & & & \\
\hline No smoking & $7(100.0)$ & $5(100.0)$ & & \\
\hline Smoking & $0(0.0)$ & $0(0.0)$ & & \\
\hline Body mass index; $n$ (SD) & $27.4(6.2)$ & $29.1(11.2)$ & & \\
\hline Surgery characteristics & Machined $(n=7)$ & Polished $(n=5)$ & & \\
\hline Skin thickness; millimetres (SD) & $6.4(1.9)$ & $6.7(2.6)$ & & \\
\hline Abutment length; $n$ (SD) & & & & \\
\hline 6 & $1(14.3)$ & $0(0.0)$ & & \\
\hline 9 & $5(71.4)$ & $3(60.0)$ & & \\
\hline 12 & $1(14.3)$ & $2(40.0)$ & & \\
\hline Clinical outcomes per group & & Machined & Polished & $p$ \\
\hline Maximum Holgers per patient across & 1 visits $0-12$ months & & & 0.470 \\
\hline Grade 0 & & $5(71.4)$ & $2(40.0)$ & \\
\hline Grade 1 & & $2(28.6)$ & $1(20.0)$ & \\
\hline Grade 2 & & $0(0.0)$ & $1(20.0)$ & \\
\hline Grade 3 & & $0(0.0)$ & $1(20.0)$ & \\
\hline Grade 4 & & $0(0.0)$ & $0(0.0)$ & \\
\hline Holgers across all patients and all vis & , $0-12$ months; $n$ (\% & & & 0.168 \\
\hline Grade 0 & & $21(91.3)$ & $13(68.4)$ & \\
\hline Grade 1 & & $2(8.7)$ & $3(15.8)$ & \\
\hline Grade 2 & & $0(0.0)$ & $1(5.3)$ & \\
\hline Grade 3 & & $0(0.0)$ & $2(10.5)$ & \\
\hline Grade 4 & & $0(0.0)$ & $0(0.0)$ & \\
\hline ISQ low at baseline; ISQ (SD) & & $49.6(10.9)$ & $51.2(3.3)$ & 0.81 \\
\hline ISQ low increase at 12 months; ISQ & & $8.4(5.7)$ & $2.3(11.5)$ & 0.54 \\
\hline Clinical outcomes pooled & & 3 months & 12 months & $p$ \\
\hline Holgers; $n(\%)$ & & & & 0.869 \\
\hline Grade 0 & & $9(75.0)$ & $7(77.8)$ & \\
\hline Grade 1 & & $2(16.7)$ & $1(11.1)$ & \\
\hline Grade 2 & & $0(0.0)$ & $1(11.1)$ & \\
\hline Grade 3 & & $1(8.3)$ & $0(0.0)$ & \\
\hline Grade 4 & & $0(0.0)$ & $0(0.0)$ & \\
\hline Hygiene; $n(\%)$ & & & & 1.00 \\
\hline None & & $6(50.0)$ & $5(55.6)$ & \\
\hline Minimal & & $4(33.3)$ & $3(33.3)$ & \\
\hline Moderate & & $2(16.7)$ & $1(11.1)$ & \\
\hline Abundant & & $0(0.0)$ & $0(0.0)$ & \\
\hline Pain; $n(\%)$ & & & & 0.060 \\
\hline None $(\mathrm{VAS}=0)$ & & $7(58.3)$ & $9(100.0)$ & \\
\hline Limited $(>0$ VAS $\leq 3)$ & & $4(33.3)$ & $0(0.0)$ & \\
\hline Moderate $(>3$ VAS $\leq 7$ ) & & $1(8.3)$ & $0(0.0)$ & \\
\hline Extensive $(>7$ VAS $\leq 10)$ & & $0(0.0)$ & $0(0.0)$ & \\
\hline
\end{tabular}


Table 1 (continued)

$p$ values calculated with Fisher's exact test. Hygiene is defined as amount of debris around the abutment

ISQ implant stability quotient

between baseline and 3 months (Fig. 2e), whereas no significant temporal change was shown for the rest of samples and bacterial groups.

Staphylococcus spp. were not identified at baseline, however found in all compartments after implantation at both 3 and 12 months (Fig. 2e). Biochemical identification of the isolated staphylococcal colonies revealed that several of the patients were colonised by the same species, and probably by the same strain, over the first year of BAHS implantation (Table 2). For five patients, the same species with identical biochemical numerical profile were identified at both time-points. For most patients (10/12), the same species, with identical biochemical numerical profile, was found in at least two of the three compartments at the same time-point. The common skin coloniser Staphylococcus epidermidis was identified in all patients but one (11/12), whereas the potentially harmful pathogen $S$. aureus was isolated in five of the patients. Staphylococcus lugdunensis, Staphylococcus schleiferi and Kocuria varians/rosea were isolated in a few patients.

\section{Correlation analyses}

The correlation analyses revealed several associations between clinical parameters and the microbiological results (Table 3, Online Resource 1). The analysis of specific bacterial groups showed strong positive correlations between Holgers score and pain at 3 months, and Holgers score with aerobic bacteria in the soft tissue at baseline. Similar association was shown for Holgers score at 3 months and tissue anaerobes ( 3,12 months). In addition, the CFU counts of all bacterial groups (anaerobes, aerobes, staphylococci, enterococci, E. coli) in the peri-abutment fluid space, was positively correlated with Holgers score at 12 months. The hygiene score (amount of debris around the abutment) at 12 months correlated positively with CFU of enterococci isolated from paper-points at 3 months.

For the clinical parameters, a positive correlation was demonstrated between Holgers score at 3 months and the reported pain score at the same time-point (Table 3). Further, the hygiene at 12 months was correlated with the Holgers score, 3 months after surgery as well as with the hygiene after 3 months.

For the microbiological parameters, at 3 months paperpoint sampling of aerobes, anaerobes and staphylococci correlated with abutment sampling of aerobes, anaerobes and staphylococci, respectively (Table 3). At 12 months, there was an association between paper-point and abutment $\mathrm{CFU}$ of staphylococci, and between tissue and paper-point sampling of E. coli.

\section{Discussion}

\section{Clinical outcome}

The present study could describe the bacterial flora on the abutment, in the surrounding exudate and in the peri-abutment soft tissue from baseline up to 12 months. Clinical parameters such as Holgers score, ISQ, hygiene, pain or numbness were in accordance with previous data for BAHS installed using tissue preservation techniques $[23,26]$ and no difference between polished and machined abutments were found.

Discrepancy of the elastic modulus between the abutment and the soft tissue produces interfacial strain concentrations, leading to micro-trauma and cell activation, resulting in a constant inflammatory state of the peri-abutment skin [15, 27]. The peri-abutment skin moves both passively when moving the head and actively because of facial movements or external forces [23]. By integrating the rigid metal abutment with the mobile soft tissue, as with the hydroxyapatitecoated abutments, the strains might increase further. Here, we hypothesised that by preventing soft tissue adhesion and integration, the soft tissue can move more freely around the abutment, counteracting the tissue strains. Moreover, a smooth abutment surface might reduce debris build-up, which may attract microbial colonisation, as well as being easier to clean. Improved clinical outcome could, however, not be revealed for the polished abutment using the conventional macroscopical clinical outcome measures. Other techniques, such as gene expression and morphology may be alternative tools to determine the impact of skin movements and strain.

\section{Bacteriological outcome}

In this study, presence of viable bacteria in all three compartments was shown. Little is known about the distribution of bacteria on and around abutments of BAHS in patients with or without peri-abutment skin infection. Although polymicrobial biofilms on fixtures, abutments, and internal screws have been detected [7], ultrastructural observations failed to detect bacteria directly adherent on the abutment surface [6]. Still, an implant surface may harbour microbes and elicit infection in the surrounding soft tissues. This is supported by experimental observations of a higher expression 
a

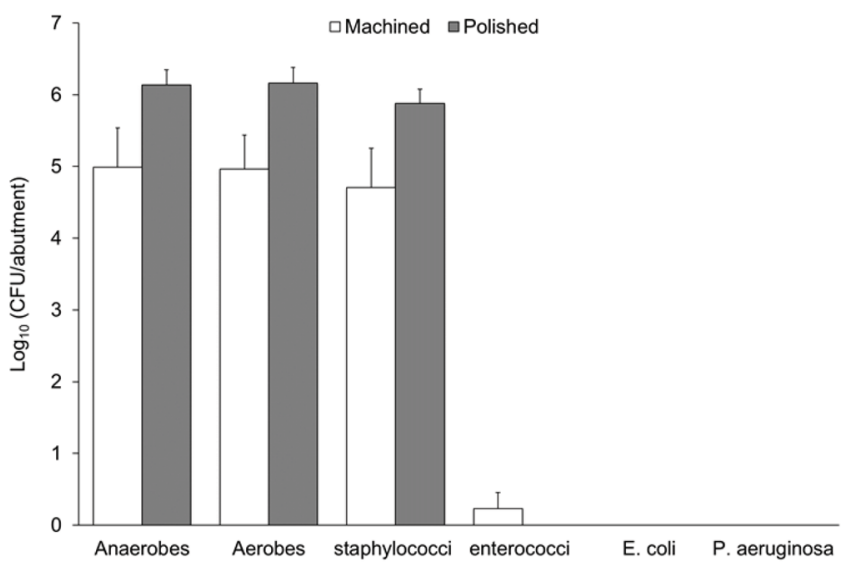

b

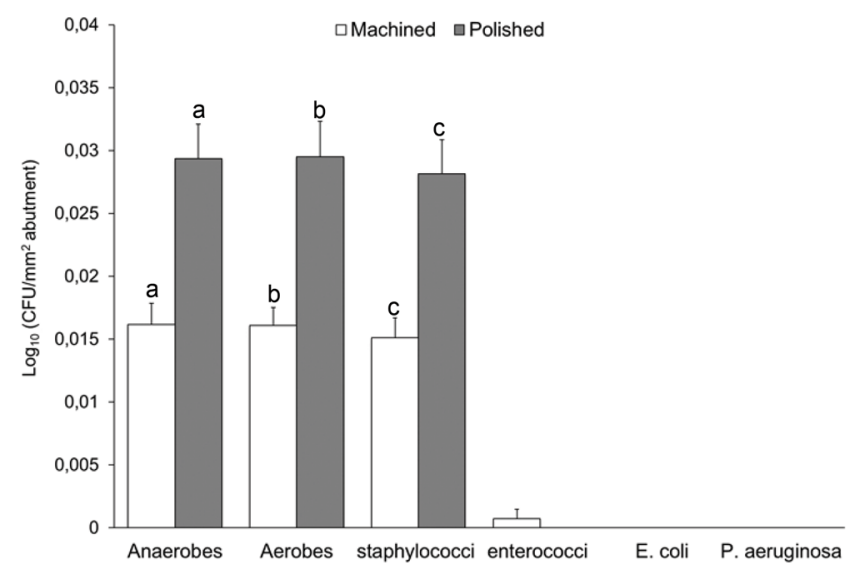

d

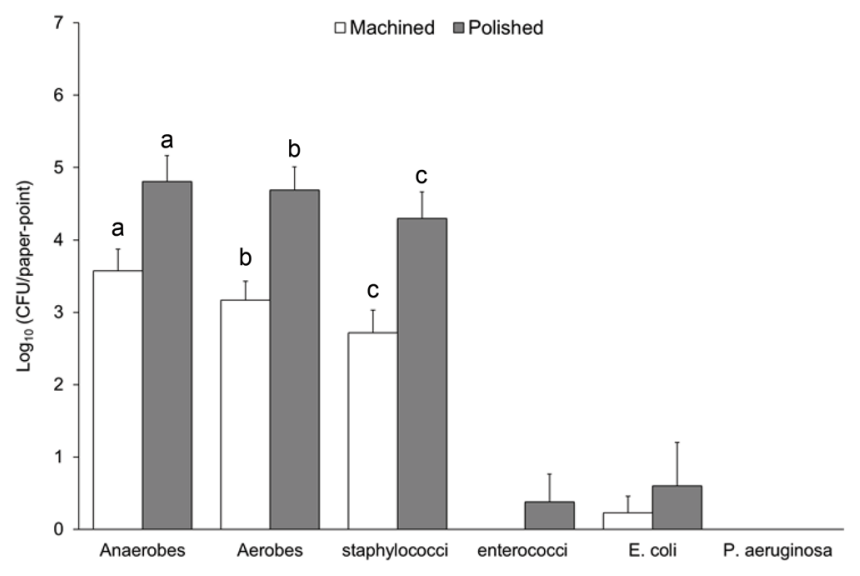

c

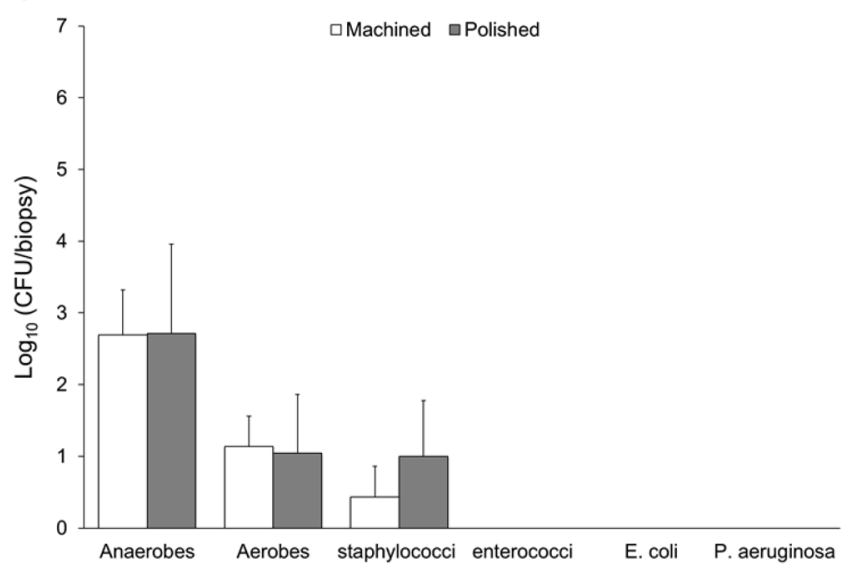

e

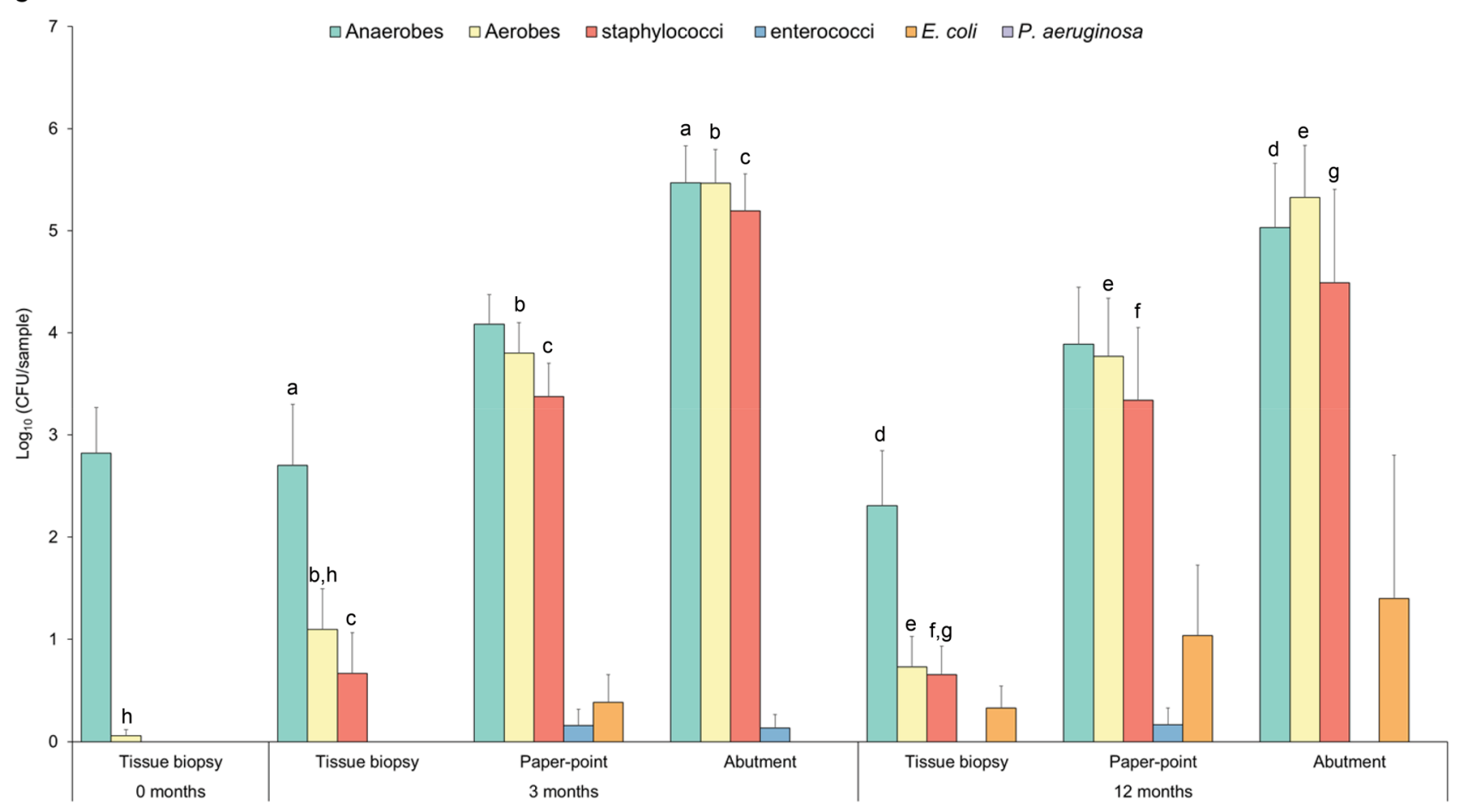


4Fig. 2 a-e Viability counts as measured by colony-forming units (CFU) of bacteria adherent on machined and polished abutments (a, b), in soft tissues (c), and on paper-points (d) retrieved at 3 months. a CFU per abutment ( $n=7$ machined; and $n=5$ polished). b CFU from abutments normalised by the surface area of the microstructure $\left(S_{\mathrm{dr}}\right)$ of the abutment; $\mathrm{CFU} / \mathrm{mm}^{2}(n=7$ machined; and $n=5$ polished). c CFU per tissue biopsy $(n=12)$. d CFU per paper-point $(n=12)$. e Viable counts (CFU/sample type) of aerobic and anaerobic bacteria as well as the aerobic bacterial species (staphylococci, enterococci, Escherichia coli, and Pseudomonas aeruginosa) at baseline $(n=12)$, 3 months $(n=12)$, and 12 months $(n=9$ biopsies, $n=9$ paper-points and $n=4$ abutments). Data represent mean \pm SEM. Bars that share the same letters are significantly different $p<0.05$

of pro-inflammatory genes at infected versus non-infected sites as well as a higher TLR2 expression (indicative of bacteria-host cell interactions) close to a colonised implant surface than further out in tissue [28].

The total number of viable bacteria on the abutment was similar for the two abutment types, however more were present on the polished if normalised to the microroughness. Even though surface topography is known to influence how microorganisms adhere and form a biofilm [29], in this study the microtopography of the two abutments was possibly too similar. However, higher CFU counts were revealed in the peri-abutment fluid for the polished group compared with the machined group. A plausible explanation is that the structural barrier between the soft tissue and the polished surface is more permissive for the downward migration of bacteria. To achieve a successful soft-tissue integration, fibroblasts must win the 'race for the surface' against microorganisms on the implant surface [10, 30]. Against the assumption that a tight structural barrier is a prerequisite, are the recent findings that tissue-integrating hydroxyapatitecoated abutments were still at risk for infection [14, 31].

How the biological processes elicited around skin-penetrating implants are related to the presence of a specific biomaterial surface morphology and microorganism is largely unknown [6, 32], and in vitro studies demonstrate contrasting results when comparing rough and smooth surfaces [33, 34]. Infection remains a challenge for porous polyethylene used for reconstruction or augmentation in the cranio-maxillo-facial region [35]. Possible factors for these infections could be a reduced tissue infiltration and vascularisation in the porous structure, allowing microorganisms to evade host defence mechanisms [36].

In this study, the surface topography did not affect the $\mathrm{CFU}$ count in the soft tissue at 3 months. The biopsies were taken a few millimetres away from the abutment, and the closer to an implant the more the material influences the biological and microbiological processes [32, 37]. Independent of infection or not, studies have shown a concentration of inflammatory cells superficial to the skin compared to deeper; and less inflammatory cells further away from the abutment $[38,39]$.
The skin is not sterile and is colonised by numerous bacteria, which are also found in deeper layers of the skin [40]. Skin disinfection before surgery removes transient superficial bacteria and reduces resident bacteria in the deeper layers. Therefore, whereas transient bacteria are easily removed, commensals are difficult to eradicate completely and can cause infections if allowed to multiply [41]. Surgical site infections can be diagnosed by the presence of clinical symptoms alone, or with more than $10^{6} \mathrm{CFU}$ of skin commensals per $\mathrm{mm}^{3}$ tissue, overcoming host's defences [42]. In this study, while abutments were colonised by $10^{3}-10^{6} \mathrm{CFU}$, the mean CFU from skin biopsies was below that level. Interestingly, for the patient with Holgers score 3 and pain score 3.5 at 3 months, there was a presence of tissue aerobes at surgery (5 CFU/biopsy) and tissue anaerobes at 3 months $\left(1.9 \times 10^{6} \mathrm{CFU} / \mathrm{biopsy}\right)$, the highest total viable counts at these time-points.

Colonisation during implant surgery, post-operative soft tissue infection, and haematogenous seeding are the main studied routes of implant-associated infection. In contrast, the infection route from within the soft tissue towards the percutaneous abutment has barely been studied [43]. An important finding in the present study was that anaerobic bacteria were already present in the tissue prior to BAHS installation despite disinfection of the skin surface. Furthermore, over time both anaerobic and aerobic bacteria were present in the soft tissue. Hence, microbes within the soft tissue could provide a route for bacterial colonisation of the abutment, a possibility demonstrated for catheter-associated infection by others [32]. The particular and multi-species microbiota, possibly found as biofilm communities on and around the abutment, provides a plausible explanation for the clinical recurrent or persistent inflammation and infection [7]. Nevertheless, colonisation per se does not necessarily imply infection, although it represents the first step of microbial infection by the accession and establishment of pathogens to the site [44]. Therefore, while colonisation is the presence of bacteria on a body surface without causing disease, infection is the invasion of host tissues by microorganisms resulting in disease [31]. The remaining question is which is the minimal infectious dose and the pathogen. Clinical guidelines for the treatment of microbial colonisation states are limited, due to a lack of knowledge of the pathogenesis of colonisation and the host-microbe relationship aspects that influence the development of infection [45]. Based on the observations of anaerobic bacteria in all three compartments evaluated, it is evident that future studies should include the detection of anaerobes to elucidate their role(s) in the microbe-host symbiosis and/or BAHS-associated infection. Staphylococci have been the most common pathogen in association with failed, retrieved BAHS fixtures and their internal screws [7]. In this study, Staphylococcus spp. were also the most commonly isolated aerobic genus 
Table 2 Staphylococcal species identification of biopsy, paper-point, and abutment samples at 3 and 12 months

\begin{tabular}{|c|c|c|c|c|c|c|}
\hline \multirow{2}{*}{$\begin{array}{l}\text { Abutment } \\
\text { (patient) }\end{array}$} & \multicolumn{3}{|l|}{3 months } & \multicolumn{3}{|l|}{12 months } \\
\hline & Biopsy & Paper-point & Abutment & Biopsy & Paper-point & Abutment \\
\hline Machined (101) & S. aureus 6736157 & S. aureus 6736157 & S. aureus 6736157 & $\begin{array}{l}\text { S. epidermidis } \\
6706116\end{array}$ & S. aureus 6736157 & S. aureus 6736157 \\
\hline Machined (102) & NDC & $\begin{array}{l}\text { S. epidermidis } \\
6706156\end{array}$ & $\begin{array}{l}\text { S. epidermidis } \\
6706156\end{array}$ & - & - & - \\
\hline Machined (103) & $\begin{array}{l}\text { S. epidermidis } \\
6704116\end{array}$ & $\begin{array}{l}\text { S. epidermidis } \\
6206117\end{array}$ & $\begin{array}{l}\text { S. epidermidis } \\
6206117\end{array}$ & $\begin{array}{l}\text { S. schleiferi } \\
6106145\end{array}$ & $\begin{array}{l}\text { S. schleiferi } \\
6106145\end{array}$ & $\begin{array}{l}\text { S. schleiferi } \\
6106145\end{array}$ \\
\hline Machined (106) & NDC & S. aureus 6736157 & $\begin{array}{l}\text { S. epidermidis } \\
6306156\end{array}$ & NDC & NDC & S. aureus 6736155 \\
\hline Machined (107) & $\begin{array}{l}\text { S. lugdunensis } \\
6316154\end{array}$ & $\begin{array}{l}\text { S. epidermidis } \\
6706116\end{array}$ & $\begin{array}{l}\text { S. epidermidis } \\
6706116\end{array}$ & NDC & $\begin{array}{l}\text { S. lugdunensis } \\
6316154\end{array}$ & $\begin{array}{l}\text { S. epidermidis } \\
6706156\end{array}$ \\
\hline Machined (108) & $\begin{array}{l}\text { S. epidermidis } \\
6702157\end{array}$ & $\begin{array}{l}\text { S. epidermidis } \\
6702157\end{array}$ & $\begin{array}{l}\text { S. epidermidis } \\
6702157\end{array}$ & - & - & - \\
\hline Machined (110) & NDC & $\begin{array}{l}\text { S. epidermidis } \\
6706117\end{array}$ & $\begin{array}{l}\text { S. epidermidis } \\
6706117\end{array}$ & $\begin{array}{l}\text { S. epidermidis } \\
6706117\end{array}$ & $\begin{array}{l}\text { S. epidermidis } \\
6706117\end{array}$ & - \\
\hline Polished (111) & NDC & $\begin{array}{l}\text { S. epidermidis } \\
6306057\end{array}$ & $\begin{array}{l}\text { S. epidermidis } \\
6306157\end{array}$ & NDC & $\begin{array}{l}\text { S. epidermidis } \\
6306117\end{array}$ & - \\
\hline & & $\begin{array}{l}\text { S. lugdunensis } \\
6716154\end{array}$ & & & $\begin{array}{l}\text { Kocuria varians/ } \\
\text { rosea } 6104004\end{array}$ & \\
\hline Polished (113) & NDC & $\begin{array}{l}\text { S. epidermidis } \\
6306117\end{array}$ & $\begin{array}{l}\text { S. epidermidis } \\
6306117\end{array}$ & $\begin{array}{l}\text { S. epidermidis } \\
6306117\end{array}$ & $\begin{array}{l}\text { S. epidermidis } \\
\quad 6716157 / 6716137\end{array}$ & - \\
\hline Polished (114) & NDC & $\begin{array}{l}\text { S. epidermidis } \\
6706117\end{array}$ & $\begin{array}{l}\text { S. epidermidis } \\
6706117\end{array}$ & NDC & $\begin{array}{l}\text { S. epidermidis } \\
6706157 \\
\text { S. aureus } 6736157\end{array}$ & - \\
\hline Polished (115) & S. aureus 6736157 & $\begin{array}{l}\text { S. aureus } 6736157 \\
\text { S. epidermidis } \\
6706117\end{array}$ & $\begin{array}{l}\text { S. aureus } 6736157 \\
\text { S. epidermidis } \\
6706117\end{array}$ & - & - & - \\
\hline Polished (116) & S. aureus 6736157 & S. aureus 6736157 & S. aureus 6736157 & S. aureus 6334056 & S. aureus 6736157 & - \\
\hline
\end{tabular}

Biochemical numerical profiles using API $^{\circledR}$ Staph strip

- sample not taken, $N D C$ no detected colonies on selective staphylococci agar

across all samples and time-points. It is well known that $S$. aureus constitutes a risk factor for the development of skin, soft tissue, and systemic infections [19, 46], and in this study it was detected in $5 / 12$ patients. This is in agreement with the detection of $S$. aureus in $47 \%$ of patients with percutaneous bone-anchored lower limb amputation prostheses [47].

\section{Associations between clinical and microbiological outcomes}

Although the use of the Holgers score has been questioned recently $[47,48]$, the present data indicate that there is an association between Holgers score and the number of bacteria in the peri-abutment fluid and surrounding tissue, as well as with pain scores. While $P$. aeruginosa was not detected, 4 patients were colonised by $E$. coli of which one was colonised at both 3 and 12 months. The isolation of $E$. coli from the peri-implant fluid space at 3 months correlated with an increased Holgers score at 12 months. In general, Gram-negative bacteria are not part of the skin microbiota, and their detection in skin samples is probably due to contamination from the gastrointestinal tract [49]. These findings stress the need for efficient disinfection before implantation and the implementation of an efficient patient-cleaning regimen. The associations between the amount of debris around the abutment at 3 and 12 months, between Holgers 
Table 3 Correlation analysis between clinical and microbiological parameters

\begin{tabular}{|c|c|c|c|}
\hline \multirow[t]{2}{*}{ Clinical parameters } & \multirow[t]{2}{*}{ Microbiological parameters (CFU) } & \multicolumn{2}{|l|}{ Pooled } \\
\hline & & $r$ & $p$ \\
\hline \multirow[t]{3}{*}{ Holgers at $3 \mathrm{~m}$} & Tissue aerobes at baseline & 0.904 & $<0.001$ \\
\hline & Tissue anaerobes at $3 \mathrm{~m}$ & 0.626 & 0.029 \\
\hline & Tissue anaerobes at $12 \mathrm{~m}$ & 0.680 & 0.044 \\
\hline Pain at $3 \mathrm{~m}$ & Tissue aerobes at baseline & 0.701 & 0.011 \\
\hline \multirow[t]{5}{*}{ Holgers at $12 \mathrm{~m}$} & Paper-point aerobes at $3 \mathrm{~m}$ & 0.745 & 0.021 \\
\hline & Paper-point anaerobes at $3 \mathrm{~m}$ & 0.819 & 0.007 \\
\hline & Paper-point staphylococci at $3 \mathrm{~m}$ & 0.705 & 0.034 \\
\hline & Paper-point enterococci at $3 \mathrm{~m}$ & 0.884 & 0.002 \\
\hline & Paper-point $E$. coli at $3 \mathrm{~m}$ & 0.736 & 0.024 \\
\hline Hygiene at $12 \mathrm{~m}$ & Paper-point enterococci at $3 \mathrm{~m}$ & 0.746 & 0.021 \\
\hline \multirow[t]{2}{*}{ Clinical parameters } & \multirow[t]{2}{*}{ Clinical parameters } & \multicolumn{2}{|l|}{ Pooled } \\
\hline & & $r$ & $p$ \\
\hline Holgers at $3 \mathrm{~m}$ & Pain at $3 \mathrm{~m}$ & 0.733 & 0.007 \\
\hline Holgers at $3 \mathrm{~m}$ & Hygiene at $12 \mathrm{~m}$ & 0.737 & 0.023 \\
\hline Hygiene at $3 \mathrm{~m}$ & Hygiene at $12 \mathrm{~m}$ & 0.763 & 0.017 \\
\hline \multirow[t]{2}{*}{ Microbiological parameters (CFU) } & \multirow[t]{2}{*}{ Microbiological parameters (CFU) } & \multicolumn{2}{|l|}{ Pooled } \\
\hline & & $r$ & $p$ \\
\hline \multirow[t]{5}{*}{ Tissue aerobes at $3 \mathrm{~m}$} & Tissue aerobes at $12 \mathrm{~m}$ & 0.810 & 0.008 \\
\hline & Tissue staphylococci at $3 \mathrm{~m}$ & 0.906 & 0.000 \\
\hline & Tissue staphylococci at $12 \mathrm{~m}$ & 0.866 & 0.003 \\
\hline & Paper-point enterococci at $3 \mathrm{~m}$ & 0.715 & 0.009 \\
\hline & Paper-point $E$. coli at $3 \mathrm{~m}$ & 0.895 & $<0.001$ \\
\hline \multirow[t]{6}{*}{ Paper-point aerobes at $3 \mathrm{~m}$} & Abutment aerobes at $3 \mathrm{~m}$ & 0.729 & 0.007 \\
\hline & Tissue aerobes at $12 \mathrm{~m}$ & 0.683 & 0.043 \\
\hline & Paper-point anaerobes at $3 \mathrm{~m}$ & 0.868 & $<0.001$ \\
\hline & Abutment anaerobes at $3 \mathrm{~m}$ & 0.593 & 0.042 \\
\hline & Paper-point staphylococci at $3 \mathrm{~m}$ & 0.898 & $<0.001$ \\
\hline & Abutment staphylococci at $3 \mathrm{~m}$ & 0.706 & 0.010 \\
\hline \multirow[t]{4}{*}{ Abutment aerobes at $3 \mathrm{~m}$} & Paper-point anaerobes at $3 \mathrm{~m}$ & 0.770 & 0.003 \\
\hline & Abutment anaerobes at $3 \mathrm{~m}$ & 0.941 & $<0.001$ \\
\hline & Paper-point staphylococci at $3 \mathrm{~m}$ & 0.780 & 0.003 \\
\hline & Abutment staphylococci at $3 \mathrm{~m}$ & 0.973 & $<0.001$ \\
\hline \multirow[t]{4}{*}{ Tissue aerobes at $12 \mathrm{~m}$} & Tissue anaerobes at $3 \mathrm{~m}$ & 0.810 & 0.008 \\
\hline & Tissue staphylococci at $3 \mathrm{~m}$ & 0.717 & 0.030 \\
\hline & Tissue staphylococci at $12 \mathrm{~m}$ & 0.759 & 0.018 \\
\hline & Paper-point E. coli at $3 \mathrm{~m}$ & 0.698 & 0.037 \\
\hline \multirow[t]{3}{*}{ Paper-point aerobes at $12 \mathrm{~m}$} & Paper-point anaerobes at $12 \mathrm{~m}$ & 0.974 & $<0.001$ \\
\hline & Paper-point staphylococci at $12 \mathrm{~m}$ & 0.976 & $<0.001$ \\
\hline & Abutment staphylococci at $12 \mathrm{~m}$ & 0.950 & 0.050 \\
\hline Tissue anaerobes at $0 \mathrm{~m}$ & Abutment enterococci at $3 \mathrm{~m}$ & -0.577 & 0.050 \\
\hline \multirow[t]{3}{*}{ Paper-point anaerobes at $3 \mathrm{~m}$} & Abutment anaerobes at $3 \mathrm{~m}$ & 0.757 & 0.004 \\
\hline & Paper-point staphylococci at $3 \mathrm{~m}$ & 0.894 & $<0.001$ \\
\hline & Abutment staphylococci at $3 \mathrm{~m}$ & 0.737 & 0.006 \\
\hline \multirow[t]{2}{*}{ Abutment anaerobes at $3 \mathrm{~m}$} & Paper-point staphylococci at $3 \mathrm{~m}$ & 0.751 & 0.005 \\
\hline & Abutment staphylococci at $3 \mathrm{~m}$ & 0.924 & $<0.001$ \\
\hline
\end{tabular}


Table 3 (continued)

\begin{tabular}{|c|c|c|c|}
\hline \multirow[t]{2}{*}{ Microbiological parameters (CFU) } & \multirow[t]{2}{*}{ Microbiological parameters (CFU) } & \multicolumn{2}{|l|}{ Pooled } \\
\hline & & $r$ & $p$ \\
\hline \multirow[t]{2}{*}{ Paper-point anaerobes at $12 \mathrm{~m}$} & Paper-point staphylococci at $12 \mathrm{~m}$ & 0.924 & $<0.001$ \\
\hline & Paper-point enterococci at $12 \mathrm{~m}$ & -0.718 & 0.029 \\
\hline \multirow[t]{3}{*}{ Tissue staphylococci at $3 \mathrm{~m}$} & Tissue staphylococci at $12 \mathrm{~m}$ & 0.844 & 0.004 \\
\hline & Paper-point enterococci at $3 \mathrm{~m}$ & 0.764 & 0.004 \\
\hline & Paper-point $E$. coli at $3 \mathrm{~m}$ & 0.965 & $<0.001$ \\
\hline \multirow[t]{2}{*}{ Paper-point staphylococci at $3 \mathrm{~m}$} & Abutment staphylococci at $3 \mathrm{~m}$ & 0.768 & 0.004 \\
\hline & Abutment staphylococci at $12 \mathrm{~m}$ & 0.952 & 0.048 \\
\hline Tissue staphylococci at $12 \mathrm{~m}$ & Paper-point $E$. coli at $3 \mathrm{~m}$ & 0.798 & 0.010 \\
\hline Paper-point staphylococci at $12 \mathrm{~m}$ & Abutment staphylococci at $12 \mathrm{~m}$ & 0.998 & 0.002 \\
\hline Paper-point enterococci at $3 \mathrm{~m}$ & Paper-point E. coli at $3 \mathrm{~m}$ & 0.873 & $<0.001$ \\
\hline Tissue $E$. coli at $12 \mathrm{~m}$ & Paper-point $E$. coli at $12 \mathrm{~m}$ & 0.996 & $<0.001$ \\
\hline
\end{tabular}

The data show clinical parameters that revealed significant positive or negative correlations with bacterial count in the three different compartments (in the tissue, in the peri-implant exudate and on the abutment). Pearson coefficients $(r)$ and level of significance $(p)$ are presented; $n=9-12$. In the analysis patients with both types of abutments were pooled

score at 3 months and amount of debris later at 12 months, and between Holgers score at 12 months and CFU counts from most bacterial species retrieved by paper-points at 3 months, indicate the importance of the individual compliance with the cleaning regimen.

\section{Sampling methods and strength and limitations of study}

Although genomic approaches to characterise the skin bacterial flora have shown a much greater diversity of organisms than culture-based methods, the latter are the standard use in clinical microbiology for the detection and quantification of bacteria in samples. Genomic approaches cannot provide information if the bacterial species found are alive or viable like with culturing, although it is also known than certain species are difficult to culture and may go undetected. To increase bacterial detection, additional enrichment of the samples in TAS media for additional 5 days was performed. In this study, selective media to evaluate Propionibacterium spp were not included. Fungal-associated dermatologic diseases could also play a role for BAHS [50]; however, fungi and viruses were not evaluated from the obtained samples.

Sampling from the three compartments enabled studies on the relationship between clinical macroscopical observations and microbiological findings. To our knowledge, this is the first time in the field of BAHS where the microbiological status in the tissue, in the space between abutment and tissue, and on the abutment, is evaluated over time.

Prior to acquiring knowledge on the mechanism of BAHS-associated infection, it is not possible to advocate a specific compartment as more important for the microbiological sampling. The paper-point sampling has definite advantages as being non-invasive, and allowing standardisation. Moreover, this method was found to provide the largest number of correlations with other parameters at 3 months (paper-point $>$ tissue $>$ abutment). The soft-tissue biopsy enabled quantitative CFU determinations, but the variation in biopsy size presents an obvious difficulty with normalisation and intra- and inter-patient comparisons (between compartments and between patients). Sampling bacteria from the abutment suffers the weakness of a necessary removal of the abutment. For example, due to a more complex and more invasive approach than what was anticipated, the abutment removal and sampling at 12 months was discontinued (resulting in fewer abutment samples at this time-point).

\section{Conclusions and clinical implications}

- The modification of the abutment topography did not affect the clinical outcome during the first year of a BAHS.

- Sampling from three different compartments (soft tissue biopsy, peri-abutment fluid space and abutment) allowed the isolation and quantitative determination of the number of viable bacteria.

- Several correlations were found between the clinical and the microbiological findings.

- The detection of anaerobic bacteria in skin biopsies prior to BAHS installation and subsequently in all three compartments, motivates further studies on their characterisation and putative role in the BAHS-associated microbiome and infection.

- In the peri-abutment space exclusively, a significantly higher amount of anaerobes, aerobes and staphylococci 
were demonstrated for polished versus machined abutments.

- Biochemical identification of staphylococci showed that the skin commensal S. epidermidis and pathogen $S$. aureus were common species. The presence of $S$. aureus represents a risk factor for the development of BAHSassociated infections.

Taken together, ahead of a large clinical trial, the present pilot trial largely confirmed a suitable study design, sampling and analytical methodology to determine the effects of modified abutment properties.

Acknowledgements We thank Simon Isaksson and Martin Andersson at Division of Applied Chemistry, Department of Chemistry and Chemical Engineering, Chalmers University of Technology (Gothenburg, Sweden) for their support during the contact angle analysis. This study was sponsored by Oticon Medical AB, Sweden (Study ID C49) and supported by the Swedish Research Council (K201552X-09495-28-4), the ALF/LUA Research Grant (ALFGBG-448851), The Foundation for Strategic Research (SSF) (ID16-0036), the Hjalmar Svensson Foundation, the Felix Neubergh Foundation, the Adlerbertska Foundation, the IngaBritt and Arne Lundberg Foundation, the Vilhelm and Martina Lundgren Vetenskapsfond and the Area of Advance Materials of Chalmers and GU Biomaterials within the Strategic Research Area initiative launched by the Swedish Government.

\section{Compliance with ethical standards}

Conflict of interest MLJ, SJ, HP are employees of Oticon Medical. The other authors declare no conflict of interest.

Open Access This article is distributed under the terms of the Creative Commons Attribution 4.0 International License (http://creativeco mmons.org/licenses/by/4.0/), which permits unrestricted use, distribution, and reproduction in any medium, provided you give appropriate credit to the original author(s) and the source, provide a link to the Creative Commons license, and indicate if changes were made.

\section{References}

1. Kiringoda R, Lustig LR (2013) A meta-analysis of the complications associated with osseointegrated hearing aids. Otol Neurotol Off Publ Am Otol Soc Am Neurotol Soc Eur Acad Otol Neurotol 34(5):790-794. https://doi.org/10.1097/MAO.0b013 e318291c651

2. Verheij E, Bezdjian A, Grolman W, Thomeer HG (2016) A systematic review on complications of tissue preservation surgical techniques in percutaneous bone conduction hearing devices. Otol Neurotol Off Publ Am Otol Soc Am Neurotol Soc Eur Acad Otol Neurotol 37(7):829-837. https://doi.org/10.1097/ MAO.0000000000001091

3. Shah FA, Johansson ML, Omar O, Simonsson H, Palmquist A, Thomsen P (2016) Laser-modified surface enhances osseointegration and biomechanical anchorage of commercially pure titanium implants for bone-anchored hearing systems. PLoS One 11(6):e0157504. https://doi.org/10.1371/journal.pone.0157504

4. Larsson A, Andersson M, Wigren S, Pivodic A, Flynn M, Nannmark U (2015) Soft tissue integration of hydroxyapatitecoated abutments for bone conduction implants. Clin Implant
Dent Relat Res 17 Suppl 2:e730-735. https://doi.org/10.1111/ cid. 12304

5. Gotfredsen K, Berglundh T, Lindhe J (2000) Anchorage of titanium implants with different surface characteristics: an experimental study in rabbits. Clin Implant Dent Relat Res 2(3):120-128

6. Holgers KM, Thomsen P, Tjellstrom A, Ericson LE (1995) Electron microscopic observations on the soft tissue around clinical long-term percutaneous titanium implants. Biomaterials 16(2):83-90

7. Monksfield P, Chapple IL, Matthews JB, Grant MM, Addison O, Reid AP, Proops DW, Sammons RL (2011) Biofilm formation on bone-anchored hearing aids. J Laryngol Otol 125(11):11251130. https://doi.org/10.1017/S0022215111002143

8. van Hoof M, Wigren S, Duimel H, Savelkoul PH, Flynn M, Stokroos RJ (2015) Can the hydroxyapatite-coated skin-penetrating abutment for bone conduction hearing implants integrate with the surrounding skin? Front Surg 2:45. https://doi. org/10.3389/fsurg.2015.00045

9. Holgers KM, Ljungh A (1999) Cell surface characteristics of microbiological isolates from human percutaneous titanium implants in the head and neck. Biomaterials 20(14):1319-1326

10. Gristina AG (1987) Biomaterial-centered infection: microbial adhesion versus tissue integration. Science 237(4822):1588-1595

11. Elek SD, Conen PE (1957) The virulence of Staphylococcus pyogenes for man; a study of the problems of wound infection. Br J Exp Pathol 38(6):573-586

12. Rompen E, Domken O, Degidi M, Pontes AE, Piattelli A (2006) The effect of material characteristics, of surface topography and of implant components and connections on soft tissue integration: a literature review. Clin Oral Implants Res 17(Suppl 2):55-67. https ://doi.org/10.1111/j.1600-0501.2006.01367.x

13. Hogsbro M, Agger A, Johansen LV (2017) Bone anchored hearing implant surgery: 1 year follow-up data shows no effect of hydroxyapatite coating on soft tissue reaction after loading at 1 week. Otol Neurotol Off Publ Am Otol Soc Am Neurotol Soc Eur Acad Otol Neurotol 38 (6):e152-e158. https://doi.org/10.1097/ MAO.0000000000001442

14. Hultcrantz $M$ (2017) Case report after introducing a new abutment surface for bone anchored hearing implants: hydroxiapatite abutment surfaces and skin reaction. J Med Imp Surg 2(1):115

15. Hilborn J, Bjursten LM (2007) A new and evolving paradigm for biocompatibility. J Tissue Eng Regen Med 1(2):110-119. https:// doi.org/10.1002/term.4

16. Larsson C, Thomsen P, Aronsson BO, Rodahl M, Lausmaa J, Kasemo B, Ericson LE (1996) Bone response to surface-modified titanium implants: studies on the early tissue response to machined and electropolished implants with different oxide thicknesses. Biomaterials 17(6):605-616

17. Holgers KM, Roupe G, Tjellstrom A, Bjursten LM (1992) Clinical, immunological and bacteriological evaluation of adverse reactions to skin-penetrating titanium implants in the head and neck region. Contact Dermat 27(1):1-7

18. Leeming JP, Holland KT, Cunliffe WJ (1984) The microbial ecology of pilosebaceous units isolated from human skin. J Gen Microbiol 130(4):803-807. https://doi.org/10.1099/00221 287-130-4-803

19. Grice EA, Kong HH, Conlan S, Deming CB, Davis J, Young AC, Program NCS, Bouffard GG, Blakesley RW, Murray PR, Green ED, Turner ML, Segre JA (2009) Topographical and temporal diversity of the human skin microbiome. Science 324(5931):1190-1192. https://doi.org/10.1126/science.1171700

20. Grice EA, Segre JA (2011) The skin microbiome. Nat Rev Microbiol 9(4):244-253. https://doi.org/10.1038/nrmicro2537

21. Roth RR, James WD (1989) Microbiology of the skin: resident flora, ecology, infection. J Am Acad Dermatol 20(3):367-390 
22. Johansson ML, Stokroos RJ, Banga R, Hol MK, Mylanus EA, Savage Jones H, Tysome JR, Vannucchi P, Hof JR, Brunings JW, van Tongeren J, Lutgert RW, Banerjee A, Windfuhr JP, Caruso A, Giannuzzi AL, Bordin S, Hanif J, Schart-Moren N, Singam S, Jonhede S, Holmberg M, Cremers CW, Hultcrantz M (2017) Short-term results from seventy-six patients receiving a boneanchored hearing implant installed with a novel minimally invasive surgery technique. Clin Otolaryngol Off J ENT UK Off J Neth Soc Oto Rhino Laryngol Cerv Fac Surg 42(5):1043-1048. https ://doi.org/10.1111/coa.12803

23. Calon TGA, Johansson ML, de Bruijn AJG, van den Berge H, Wagenaar M, Eichhorn E, Janssen AML, Hof JR, Brunings JW, Joore MA, Jonhede S, van Tongeren J, Holmberg M, Stokroos RJ (2017) Minimally invasive ponto surgery versus the linear incision technique with soft-tissue preservation for bone conduction hearing implants: a multicentre, randomised, controlled trial. Otol Neurotol Off Publ Am Otol Soc Am Neurotol Soc Eur Acad Otol Neurotol. Accepted for publication

24. Unit S Bacteriology. B 44, UK Standards for Microbiology Investigations: Investigation of Prosthetic Joint Infection Samples. Issue no: 1.2 , Issue date: 01.08 .2012

25. Charalampakis G (2013) Peri-implantitis from a microbiological perspective. Doctoral thesis, University of Gothenburg. Sahlgrenska Academy

26. Hultcrantz M (2011) Outcome of the bone-anchored hearing aid procedure without skin thinning: a prospective clinical trial. Otol Neurotol Off Publ Am Otol Soc Am Neurotol Soc Eur Acad Otol Neurotol 32(7):1134-1139. https://doi.org/10.1097/MAO.0b013 e31822a1c47

27. Holt B, Tripathi A, Morgan J (2008) Viscoelastic response of human skin to low magnitude physiologically relevant shear. J Biomech 41(12):2689-2695. https://doi.org/10.1016/j.jbiom ech.2008.06.008

28. Svensson S, Trobos M, Omar O, Thomsen P (2017) Site-specific gene expression analysis of implant-near cells in a soft tissue infection model-application of laser microdissection to study biomaterial-associated infection. J Biomed Mater Res Part A 105(8):2210-2217. https://doi.org/10.1002/jbm.a.36088

29. Teughels W, Van Assche N, Sliepen I, Quirynen M (2006) Effect of material characteristics and/or surface topography on biofilm development. Clin Oral implants Res 17(Suppl 2):68-81. https:// doi.org/10.1111/j.1600-0501.2006.01353.x

30. Subbiahdoss G, Pidhatika B, Coullerez G, Charnley M, Kuijer R, van der Mei HC, Textor M, Busscher HJ (2010) Bacterial biofilm formation versus mammalian cell growth on titanium-based mono- and bi-functional coating. Eur Cell Mater 19:205-213

31. Kapsokalyvas D, van Hoof M, Wigren S, Chimhanda T, Kuijpers HJ, Ramaekers FCS, Stokroos RJ, van Zandvoort M (2017) Investigating the race for the surface and skin integration in clinically retrieved abutments with two-photon microscopy. Colloids Surf B Biointerfaces 159:97-107. https://doi.org/10.1016/j.colsu rfb.2017.07.072

32. Broekhuizen CA, Schultz MJ, van der Wal AC, Boszhard L, de Boer L, Vandenbroucke-Grauls CM, Zaat SA (2008) Tissue around catheters is a niche for bacteria associated with medical device infection. Crit Care Med 36(8):2395-2402. https://doi. org/10.1097/CCM.0b013e3181818268

33. Miao X, Wang D, Xu L, Wang J, Zeng D, Lin S, Huang C, Liu X, Jiang X (2017) The response of human osteoblasts, epithelial cells, fibroblasts, macrophages and oral bacteria to nanostructured titanium surfaces: a systematic study. Int J Nanomed 12:14151430. https://doi.org/10.2147/IJN.S126760

34. Svensson S, Forsberg M, Hulander M, Vazirisani F, Palmquist A, Lausmaa J, Thomsen P, Trobos M (2014) Role of nanostructured gold surfaces on monocyte activation and Staphylococcus epidermidis biofilm formation. Int J Nanomed 9:775-794. https ://doi.org/10.2147/IJN.S51465

35. Ridwan-Pramana A, Wolff J, Raziei A, Ashton-James CE, Forouzanfar T (2015) Porous polyethylene implants in facial reconstruction: outcome and complications. J Cranio Maxillo Fac Surg Off Publ Eur Assoc Cranio Maxillo Fac Surg 43(8):1330-1334. https ://doi.org/10.1016/j.jcms.2015.06.022

36. Merritt K, Shafer JW, Brown SA (1979) Implant site infection rates with porous and dense materials. J Biomed Mater Res 13(1):101-108. https://doi.org/10.1002/jbm.820130111

37. Svensson S, Trobos M, Hoffman M, Norlindh B, Petronis S, Lausmaa J, Suska F, Thomsen P (2015) A novel soft tissue model for biomaterial-associated infection and inflammation - bacteriological, morphological and molecular observations. Biomaterials 41:106-121. https://doi.org/10.1016/j.biomaterials.2014.11.032

38. Holgers KM, Thomsen P, Tjellstrom A, Bjursten LM (1995) Immunohistochemical study of the soft tissue around long-term skin-penetrating titanium implants. Biomaterials 16(8):611-616 pii]

39. Holgers KM, Thomsen P, Tjellstrom A, Ericson LE, Bjursten LM (1994) Morphologic evaluation of clinical long-term percutaneous implants. Int J Oral Maxillofac Implants 9(6):689-697

40. Dumville JC, McFarlane E, Edwards P, Lipp A, Holmes A, Liu Z (2015) Preoperative skin antiseptics for preventing surgical wound infections after clean surgery. Cochrane Database Syst Rev (4):CD003949. https://doi.org/10.1002/14651858.CD003 949.pub4

41. Larson E (1988) Guideline for use of topical antimicrobial agents. Am J Infect Control 16(6):253-266. doi:https://doi.org/10.1016/ S0196-6553(88)80005-1

42. Mangram AJ, Horan TC, Pearson ML, Silver LC, Jarvis WR (1999) Guideline for prevention of surgical site infection, 1999. Infect Control Hosp Epidemiol 20(4):250-278. doi:https://doi. org/10.1086/501620

43. Greenfield EM, Bi Y, Ragab AA, Goldberg VM, Nalepka JL, Seabold JM (2005) Does endotoxin contribute to aseptic loosening of orthopedic implants? J Biomed Mater Res B Appl Biomater 72(1):179-185. https://doi.org/10.1002/jbm.b.30150

44. Dani A (2014) Colonization and infection. Cent Eur J Urol 67(1):86-87. https://doi.org/10.5173/ceju.2014.01.art19

45. Casadevall A, Pirofski LA (2000) Host-pathogen interactions: basic concepts of microbial commensalism, colonization, infection, and disease. Infect Immun 68(12):6511-6518

46. Schon MP, Boehncke WH (2005) Psoriasis. N Engl J Med 352(18):1899-1912. https://doi.org/10.1056/NEJMra041320

47. Lenneras M, Tsikandylakis G, Trobos M, Omar O, Vazirisani F, Palmquist A, Berlin O, Branemark R, Thomsen P (2017) The clinical, radiological, microbiological, and molecular profile of the skin-penetration site of transfemoral amputees treated with boneanchored prostheses. J Biomed Mater Res Part A 105(2):578-589. https://doi.org/10.1002/jbm.a.35935

48. Kruyt IJ, Nelissen RC, Johansson ML, Mylanus EAM, Hol MKS (2017) The IPS-scale: a new soft tissue assessment scale for percutaneous and transcutaneous implants for bone conduction devices. Clin Otolaryngol Off J ENT UK Off J Neth Soc Oto Rhino Laryngol Cervico Fac Surg 42(6):1410-1413. https://doi. org/10.1111/coa.12922

49. Roth RR, James WD (1988) Microbial ecology of the skin. Annu Rev Microbiol 42:441-464. https://doi.org/10.1146/annur ev.mi.42.100188.002301

50. Findley K, Oh J, Yang J, Conlan S, Deming C, Meyer JA, Schoenfeld D, Nomicos E, Park M, Program NIHISCCS, Kong HH, Segre JA (2013) Topographic diversity of fungal and bacterial communities in human skin. Nature 498(7454):367-370. https:// doi.org/10.1038/nature12171 